たる過程を連続的に撮撮し得る二方向連続撮影が必要で あり各方面で数多く実施されていることは象知のことで ある.この撮影では被検者の頭部固定とカセッテの支持 の困難なため従来撮影時に自ら術者が手で保持し，また 簡単な板様のすので応急的なありあわせの支持に上り不 当なX線被曝による障書をうけこれらはともに困難なも のであった。したがつて最近各所で頭部撮影台特に血管 連続撮影用のものが開発されつつあり，外国製はもらろ ん，国座にも旧常に優秀な装置ができているがどれも真 に高亚でありどこにでも容易に人手するというわけにい かない欠点がある.乙こに考案されたバラゴン X線簡易 頭頭部他管連続撮影装置は乙の撮影の琵求を渾たす簡易 な機構で便利にかつ敏速に正確に処置できる装置として 製作されている.なお本装置はすでに幾多の病院診療所 でも使用され好評である．ここでは特にこの簡易型撮影 台に問題を限定して仕様とその特徽の紨介をする。 さら に本装置に改良を加え，より完壁になるよう大うの諸氏 ご批判御指導を賜わりたい.

\section{4. カセッテ式連続撮影装置の振動}

金沢大学医学部付属病院 中员放射線部

○山本喜代志・島田 裕弘・田村 路等

\section{[目的]}

0.5 秒間隔連続撮影では読影不能になることむあり， その原因を検湖した。

\section{[方法]}

国際機械振動研究户製記録計付拢動計の振動検出器, (可動線輪方式) 連続撮影装琶の撮影位䈱中心で1, 力セ ッテの移動方向に対し A）上下, B) 面解，C）進行の 3 方向に固定し, 連続撮影装置は(1)固定继のみ, (2)固定 脚之猫車. (3)猫車のみの固定方法でカセッラは装填部に 1 枚, 撮影们置にも置く, 装填部に 2 枚重小る各状態で 送り出し振動の発生源とその時期，持続時間を，2, 装置 の固定方法と袭幅 3 , 撮影位置の藏重を $10,20,40,70 \mathrm{~kg}$ として振動の変化を测定した。

\section{[結果]}

振動の発生源はベルトの空軒 $(n)$ のみでもB）の(2)以 外では生じ，蹴爪がカセッテに揧突 $(S)$ のる，撮影流み と末撮影力セッテの撃突 $(K)$ 未撮影カセッテが Plunger へ撃突 $(P)$ ，カセッテが装填部から送出储罪へ落下 $\left(F_{1}\right)$ 撮影济みカセッテが収容部へ落下 $\left(F_{2}\right)$, の各時期でカセ ッテはベルト上の蹴爪で突飛ばされて0.43秒以内に撮影 位置にたっし，振動時間はカセッテ1. 枚当たり(3)の C) で 1.6 秒がもつとも長く（2）のA）が0.75秒でむつとも 短い. 振幅は装犆を(2)で固定するともつともすくなくB)
の $F_{2}$ が $52.5 \mu, \quad F_{1}>P>K>S(5 \mu)$ の順, C) の(1)では $P(56.3 \mu)>S(55.0 \mu)>F_{2}(43.8 \mu)>K \quad(37.5 \mu)>F_{1}$ $(35.0 \mu)$ の順にすくなくなるが，乙れがもつとむ大きい。 振動強度は固定(2)の A) の $\left.\left.S_{1} F_{1}, \mathrm{~B}\right) \circlearrowleft K_{1} P_{1} F_{2}, \mathrm{C}\right)$ の $S_{1} F_{2}$ は装填部カセッテ数の娍少ととむに翆くなり, A) の $K, P, \mathrm{~B})$ の $\left.S_{1} \mathrm{C}\right)$ の $K, P$ は返って增すとと が活淁10枚目のカ、ャッで生ずる振幅は最大時のものに 比し半分になる。かつ0.5，1.0秒の送り間隔による強度 亿有意な差はみとめられない，撮影位圆の荷重の増減と 振幅強度の間に一定の関係は見出せなかったが荷重の増 す程振幅は減少し $20 \mathrm{~kg}$ 以上の荷重でいずれも半減して いる.

\section{〔結論ならびに考察】}

1 , カセッテ式連続撮影装置は固定脚と猫車に重量を 分散するとカセッテ 1 枚の振動は 0.83 秒振幅 $53 \mu$ ，以下 で最良の状態になる。 2 , 振動は上下, 直角, 進行の 3 方向に生じ 0.5 秒間隔で使用すると振動の休止期はない. 3 , 撮影位置に $20 \mathrm{~kg}$ 以上の荷重がない上いちじるしい 振幅の抑制効果がいい.また小児軀間部では写真上に著 明なブレがみとめられぬなどから頭部前後方向で読影不 能になる現象は被写体の不安定な形状に原因すると考え 目下固定法を検討中である。なお周波数分析ができず充 分な検討が成し得なかった。

\section{X線頭部撮影装置について}

\section{東芝玉川工場}

牧野 純夫・井出昇・佐藤 雅郎

交通事故などによる頭部外傷および脳腄瘍などの撮影 を速かにかつ能率的に行なえるX線装置をフランスの放 射線装置メーカーCGR 社と，其同でとの程完成しまし た. 本装置は頭部に関するつぎの撮影が可能です。

(1) 標準撮影

患者用椅子の傾きおよび位置が自由に調整でき，管球 の可動範囲は非常に大きくかつその移動角度が目盛で読 みとれ，さらに，ブッキー台の高さおよび傾きが変えら れる棈造である。また，各移動部は軽くしかもスムーズ に動く、したがって，

(1) 位罩決めが楽に，短時間で行なえ

（2）任意の角度からの正確な撮影が繰返せ

（3）患者は楽な姿勢で，あるいはさらに患者党動加さ ないでも撮影でき

（4）立体撮影も非常に簡単である

(2) 頭㥺内集束撮影（耳鼻咽喉科領域）

撮影部位を管球の回転中心汇置いて位䈯決好す方法 でつぎの利点があります。 
（1）患者は楽な立位の姿勢がとれる

(2) 位置決めが素早くでき

（3） X線はフィルムに直角で歪みのない像が得られる

(3) 気脳室撮影, 脳室撮影

椅子に患者固定具を取り付ける，椅子の傾き变えて 造影の力所を動かすととができる.イメージも取り付け 可能である。

(4) 断層撮影

ほとんど任告の位 $L$ 置で可能で，特に気脳撮影などの洔 に威力を発揮します。

(5) その他

このような広範囲の性能を有し，しかも装置前面の床 が利用できるので，連続撮影装犆と組み合わせての脳面 管撮影などや他の分野の撮影にあ利用できまず。

\section{7"イメジアンプリファイアの開発について}

岛津製作所

田部 貞夫 $○$ 津田 元久

これまで, X線テレビショョン装置といえば遠隔操作式 透視台と組み合わせたもので，イメジアンプリファイア として9”むしくは $11 "$ を用いたものが主流をなしていた が，一般透視台にも取り付けられるような小抢軽量心゙解 像度の高いX線テレビジョン装嚚を作る目的で，7”のイ メジンプリファイアを開発した。

軽量化のために7"イメジンプリファイアはテレビシ ョン専用形とし，本体とテレビションカメラを合わせた 重量は約 $19 \mathrm{~kg}$ である。したがって，どのような簡易型 透視台にも取り付けが晋である。

7"イメジアンプリファイアを使ってX線デレビジョン を構成する場合，7゙イメジ管が解像度が高いばかりでな く, 視野と走査線および映像周波数带域幅の関係から,

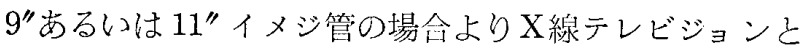
しての解像度はよくなる。

7"イメジアンプリファイアはしのほかにも，外科手術 用，治療装㽞の照準用などの分野で䉍易型 X型テレビジ ョン装置として使用するととが可能である。

またとの結果，イメジアンプリファイアとして7”，9" および $11 ” の 3$ 種類がそろったので，用途に忘じた選択 ができるようになった。

7"イメージアンプリファイアの仕様

視野 : 人才ケイ炎面で直径 $180 \mathrm{~mm}$

像の縮小率 : 10

輝度倍率: 2500 倍以上

解像度: 32 本 $/ \mathrm{cm}(0.31 \mathrm{~mm})$

出力像寸法 : 直径 $18 \mathrm{~mm}$
イメジ管容器の寸法 : $25 \mathrm{~cm} \phi \times 36 \mathrm{~cm}$

イメジ管と容器の重量 : $15 \mathrm{~kg}$

テレビジョン装置 : 三菱電機製唱

TVカメラ：ビジコン式

TV カメラの寸法 : $25 \mathrm{~cm}$ (長さ) $\times 12 \mathrm{~cm} \times 9 \mathrm{~cm}$

$\mathrm{TV}$ カメラの重量 : 約 $4 \mathrm{~kg}$ (ケーブルを含む)

\section{I.I. 用 2 現象撮影光学系}

東芝医用機器技術部 大久保寿男・星 炎二䬦

イメージインテンシファイヤ (I.I.) の辩文とともにX

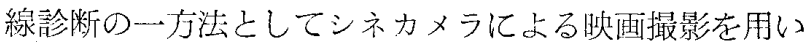
るここが多くなってきた。特に循環器のX線診断では従 来の高速フィルムチェンジャーによる直接撮影では最大 の能力を持つむのであ 1 秒に12枚しか等せないのに比べ， シネ撮影では 1 秒間 500 駒程度の高速撮影む可能である ので，像の悪さなどの久点はあってもかなりの威力を発 揮している．循環器の診断ではX線像の钼察と同時にそ の時の心電図や心内压図などを測定するととが要求され ている，従来X線像はシネフィルムに，心電図や心内压 図などはオシログラム記録紙に描かせていたため二つの 位相を合わせるととが困難であった。

この光学系はそれらの点をなくすために，X線像も 心電図や心内王図なども同じフィルム上に写し込まれる ように開発した 2 現象撮影光学系である.

主な性能を上げるとつぎのとおりである。

(1) I.I. 像を TV モニターで観察しながらシネ撮影が できる。

（2）シネフィルム上には I.I. 出力X線像と同時にそれ に同期したブラウン管像を写し込むととができる。シネ フィルム上のX線像とブラウン管像はほとんど重ならな (2.

（3）ブラウン管は高輝度残光性で 2 要素の波形を映像 する。

(4) ブラウン管像は反射鏡によって伝送されるので光 の吸收がすくなく明かるい像が得られる。

(5) タイムマークを大れるごとができる.

この光学系を使用することにより診断される生体の動 的変化を一層適確に分析し，把握できるむの上期待され る。

\section{8. 管電圧波高值の簡易測定法について}

島津製作所

[目的]

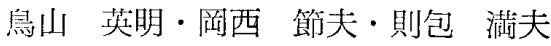

X線装翼の管電圧調整は，線質および線質を左有する 